\title{
Game Ranching: A Sustainable Land Use Option and Economic Incentive for Biodiversity Conservation in Zambia
}

\author{
Chansa Chomba ${ }^{1}$, Chimbola Obias ${ }^{2}$, Vincent Nyirenda ${ }^{3}$ \\ ${ }^{1}$ School of Agriculture and Natural Resources, Disaster Management Training Centre, Mulungushi University, \\ Kabwe, Zambia \\ ${ }^{2}$ Department of Mathematics and Statistics, Mulungushi University, Kabwe, Zambia \\ ${ }^{3}$ School of Natural Resources, Copperbelt University, Kitwe, Zambia \\ Email: ${ }^{*}$ chansachomba@rocketmail.com, ${ }^{*}$ cchomba@ac.mu.zm, ${ }^{*}$ ritachansa@yahoo.com
}

Received 23 April 2014; revised 23 May 2014; accepted 2 June 2014

Copyright (C 2014 by authors and Scientific Research Publishing Inc.

This work is licensed under the Creative Commons Attribution International License (CC BY).

http://creativecommons.org/licenses/by/4.0/

(c) $\underset{\mathrm{BY}}{\mathrm{BY}}$ Open Access

\section{Abstract}

The ten provinces of Zambia were surveyed to determine number and size of game ranches situated in these areas up to the end of 2012/early 2013. Three classes of game ranches were developed as; 1) $\geq 500$ hectares as game ranch proper, 2) $\geq 50$ - $<500$ hectares as game farm, and 3) $<50$ hectares as ornamental. A total of 200 game ranches keeping large mammals from the size of common duiker to eland were recorded with a growth rate of 6 per year for the period 1980-2012. The largest number was ornamental 98 (49\%); large game ranches were $75(38 \%)$ and the least was game farms $27(14 \%)$. Thirty seven species of large mammals were recorded, of which, 15 were the most abundant with impala topping the list with 21,000 individuals $(34 \%)$. It was found that of the ten provinces, Luapula, Western and Northern Provinces despite being largely rural with low population densities except for Luapula did not have any game ranch. The province with the largest number was Lusaka 71(36\%), Southern 59 (30\%), Central 31(16\%), Copperbelt 19 (10\%), Eastern and Northwestern 9 (4.5\% each) and Muchinga was the least with $2(1 \%)$. The rapid increase in the number of ornamental category is mainly attributed to the rise in the development of tourist accommodation facilities and high cost residential properties. This growth provides an opportunity to convert to game ranching schemes abandoned farmlands which are not currently useful to agriculture due to loss of fertility and other forms of land degradation. Similarly, parcels of land with natural ecological limitations should also be considered for such schemes. Rehabilitation of degraded land through ranching could also enhance carbon sequestration, a factor critical in minimizing carbon emissions and other green house gases.

\footnotetext{
${ }^{*}$ Corresponding author.
}

How to cite this paper: Chomba, C., Obias, C. and Nyirenda, V. (2014) Game Ranching: A Sustainable Land Use Option and Economic Incentive for Biodiversity Conservation in Zambia. Open Journal of Ecology, 4, 571-581. 


\section{Keywords}

\section{Game Ranch, Province, Number, Species, Increase, Carbon Emissions}

\section{Introduction}

Game ranching in Zambia (Figure 1) has emerged as a popular use of wildlife by the private sector. This is discerned from the rapid increase in the number of private wildlife estates from one in early 1980 to 200 by end of 2012, representing a mean establishment rate of six each year. The first private wildlife estate was established in Lusaka province, but growth of the sector has now covered seven of the ten provinces. At the time the first game ranch was established, there was no policy or legislative framework to guide and facilitate its growth [1] [2]. The only provision made available was the Statutory Instrument on Licences and Fees, which provided a discount of 50\% for all live wild animals sold to individuals stocking game ranching schemes. This provision was initially intended to encourage indigenous Zambians to establish and manage game ranches as an alternative land use option to conventional agriculture and livestock keeping. Over the years, government realized the need to regulate the sector through Policy and Legislative frameworks. The policy for National Parks and Wildlife in Zambia of 1998 and the Zambia Wildlife Act of 1998 provided the required legislative frameworks to support the growth of the game ranching sector.

After the establishment of the first Game Ranch in Lusaka Province, the Southern Province of Zambia adopted and recorded a faster rate of increase in the establishment and growth of private wildlife estates. This is assumed to be attributed to the cattle keeping tradition of the local tribes and the large scale cattle ranching schemes by white farmers of mainly British and South African descent which is also a factor behind animal husbandry skills inherent in the people of the province. This factor, coupled with the occasional outbreaks of cattle diseases such as Foot and Mouth Disease (FMD), Contagious Bovine Pleuro-Pneumonia (CBPP) and others are assumed to have inspired many livestock keepers in the province to switch to game ranching as a complement to livestock keeping. However, most of the game ranch owners are mixed race and white settlers who had acquired large tracts of land for cattle keeping and crop cultivation before and shortly after independence [2]. The second phase of rapid growth in the number of private wildlife estates was recorded when there was an increased in flow of white migrants from South Africa after 1994, and Zimbabwe during land ownership disputes respectively. These latter groups brought with them new skills in game ranching. Their experience in the sector encouraged some local farmers to switch to game ranching.

In the east and southern African sub regions, particularly in the Southern African Development Community (SADC) in general, game ranching has been increasing more rapidly than any other part of Africa and has emerged as a desirable alternative to traditional ways of using land. In South Africa, for instance, there were more than 10,000 game ranches in 2012 [2] [3], up from 5000 in 2003 as recorded by ABSA [4], occupying over 20.5 million hectares of land or above $17 \%$ of the country's available land under private conservation, which was more than double the 7.5 million hectares of the national and provincial reserves combined [2] [3] [5]. Game ranches generated over US\$400 million annually through mainly live auctions and trophy hunting and there were more game animals of some species in South Africa than the previous century, save for the rhino which has recently been persecuted due to the sudden emergence of a new white and black rhino (Ceratotherium simum and Diceros bicornis) horn market in Asia. For instance, there were about 30,000 African buffalo (Syncerus caffer) of which 90\% were disease free on 1918 game ranches [3] [5].

Experiences on the profitability of game ranching when compared with livestock particularly in marginal areas obtained from countries such as, Zimbabwe, Namibia and South Africa inspired Zambia to enhance its policies and legislation on ranching in order to support growth of the sector. Although the sector is described as being relatively new, it has now gained momentum such that it now includes; leopard tortoise (Stigmochelys pardalis) bell's hinged (Kinixys belliana) and pancake (Malacochersus tornieri), keeping of birds and snakes, large mammals and Nile crocodile (Crocodylus niloticus) on a commercial scale. Tortoise farming in particular, increased after the Convention on International Trade in Endangered Species of Wild Fauna and Flora (CITES) imposed a non time bound moratorium on live exports of tortoises from Zambia, as it was assumed that the live pancake tortoises that were being exported from Zambia were smuggled specimens from Tanzania. Government 


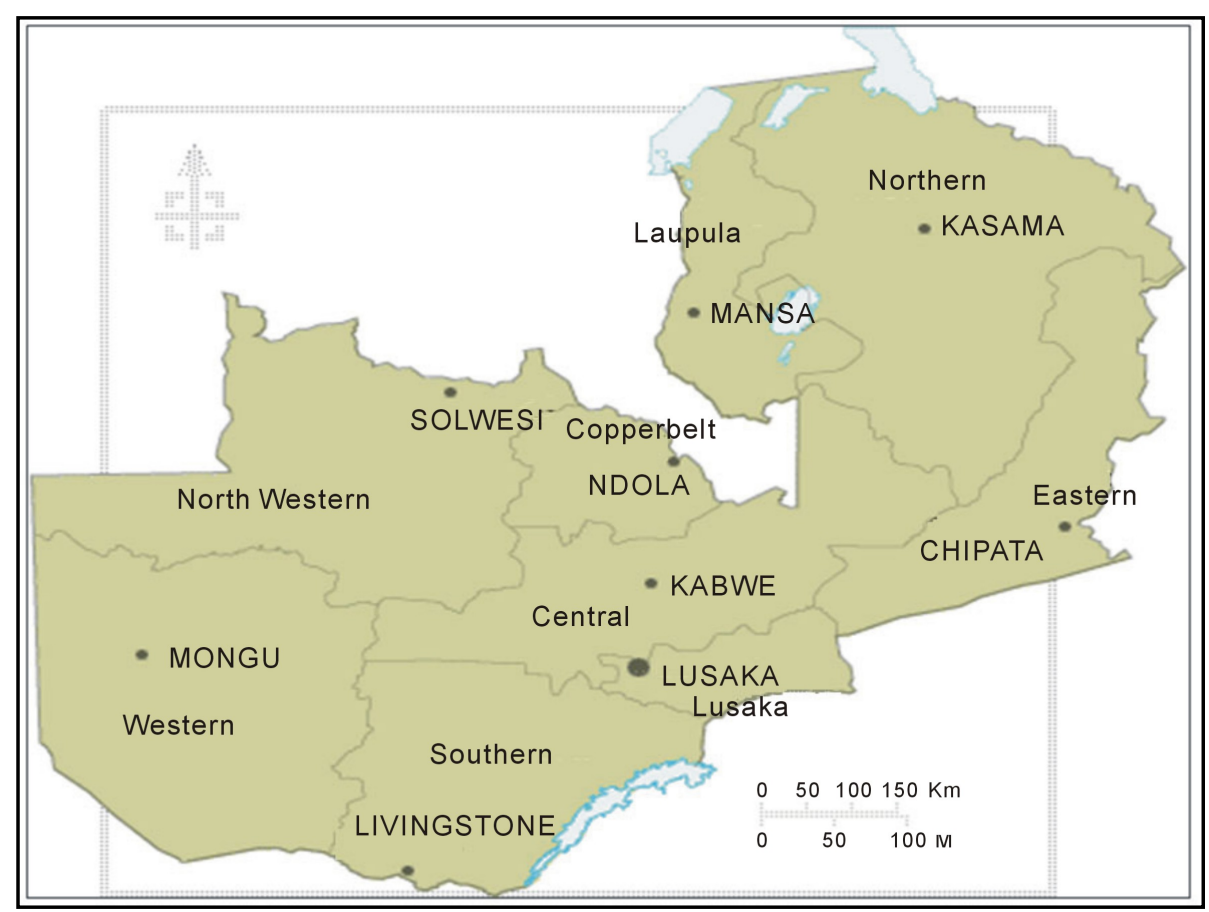

(a)

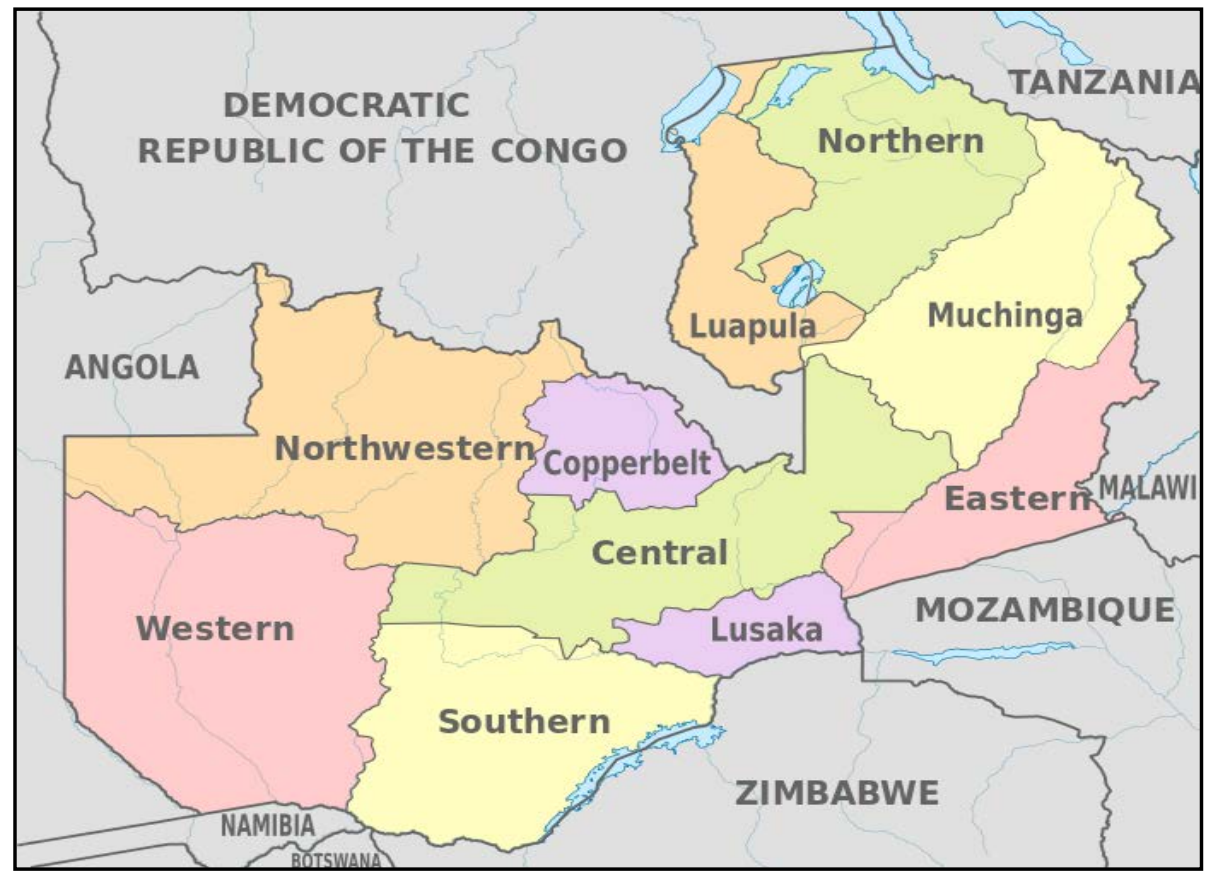

(b)

Figure 1. (a) Location of Zambia and its nine provinces, in relation to other Southern Africa countries before the subdivision in 2011; (b) After the subdivision in 2011 which created the tenth province, Muchinga.

was left with no option but to carry out field research to establish the existence of pan cake in Zambia [6], to dispel the anecdotal reports of smuggling between Zambia and Tanzania. After the species was discovered in North eastern Zambia [6], government encouraged captive breeding of the three species of tortoises with permission from CITES. Trade eventually resumed and a number of people ventured into this new enterprise. Since 
tortoises can be bred on limited space in back yards and requires minimal capital investments, many small scale farmers took up the challenge [7]-[9].

This paper focused on game ranches where large mammals are kept for trophy hunting and photographic tourism as well as enhancing aesthetic beauty for purely ornamental purposes such as on hotel premises and high cost residential properties. It provided an analysis of the characteristics of private wildlife estates and their patterns of distribution throughout the 10 provinces of Zambia for potential farmers to use in deciding on suitable location, size and species of interest, and how to overcome ecological and socioeconomic related obstacles in the establishment of PWEs in provinces such as Northwestern, Luapula and Northern Provinces which seem to be lagging behind. It could also be a useful tool in lobbying for customary land through traditional authorities (chiefs) especially for game ranching which requires more land than monoculture. It is hoped that the conclusions from this study will also stimulate local academic institutions such as the University of Zambia, Copperbelt and Mulungushi Universities to offer courses that would provide the needed technical expertise in the sector. The land policy also imposes a severe limitation by restricting the extent of land to be alienated for agriculture to 250 hectares which is not adequate for game ranching, hence the provision of technical information on the land size requirements would help remove this barrier of size limitation which is caused by paucity of data.

\section{Methods and Materials}

Data on the number of private wildlife estates covering all the provinces of Zambia (Figure 1) followed the method of retrieving information stored in the directorate of research and licencing office of the Zambia Wildlife Authority (ZAWA). Duplicate copies of the Certificate of Ownership (CO) and Permit to Keep Wild animals in Captivity which are stored at ZAWA were accessed. Both the CO and Permit to Keep animals in Captivity are issued to all private wildlife estates and are renewed annually which guaranteed up to date data on the performance of the sector. The forms also contain all the species and numbers kept by each private property, area in hectares of the property, name of the property and the owner's name.

Forms described above, provide details on species name, sex, and numbers, category of private wildlife estate (e.g. game ranch or crocodile farm), size in hectares, location of the property, and year established. Such data were entered on data sheets.

Basic statistical analyses using Microsoft Excel 2007, and Minitab Software Programme Version 14 were applied to process and present results. Game Ranch sizes were classified on the basis of their size as follows; $\geq 500$ hectares as game ranch proper, $<500$ hectares but $>50$ hectares as game farm and 50 hectares and less as ornamental.

\section{Results}

\subsection{Total Number of Game Ranches Based on Size in Hectares}

By end of year 2012, there were 200 game ranches of different sizes in Zambia representing a moderate annual growth rate of $6(3 \%)$ per year in the last 32 years. The national pattern was such that ornamental properties were the most abundant 98 (49\%) and these were less than 50 hectares in extent, mainly located around residential properties, hotels and other tourist facilities; Game ranches of size $\geq 500$ hectares 75 (38\%) ranked second with the least being game farms of intermediate size 50 - 499 hectares which recorded 27 (14\% of national total) (Figure 2).

\subsection{Number of Game Ranches in Each Province}

\subsubsection{Comparison of Size of Province, Human Population Density and Number of Private Wildlife Estates}

The number and size of game ranches were not determined by the size of province or human population density $(\mathrm{P}<0.05)$. Lusaka Province which is the smallest $\left(21,896 \mathrm{~km}^{2}\right)$ and which also had the highest human density per sq kilometer $\left(100.4 / \mathrm{km}^{2}\right)$ had the largest number of game ranches at national level of 71 (36\% of national total). Of this total, the largest number were ornamental properties 46 (65\%), followed by game ranches were 15 (21\%) and the least were game farms 10 (14\%). The second largest number were in Southern Province with a combined total of 59 (30\% of national total), of which ornamental properties were 29 (49\%), game ranch proper 21 (36\%) and the least were game farms 9 (15\%). 


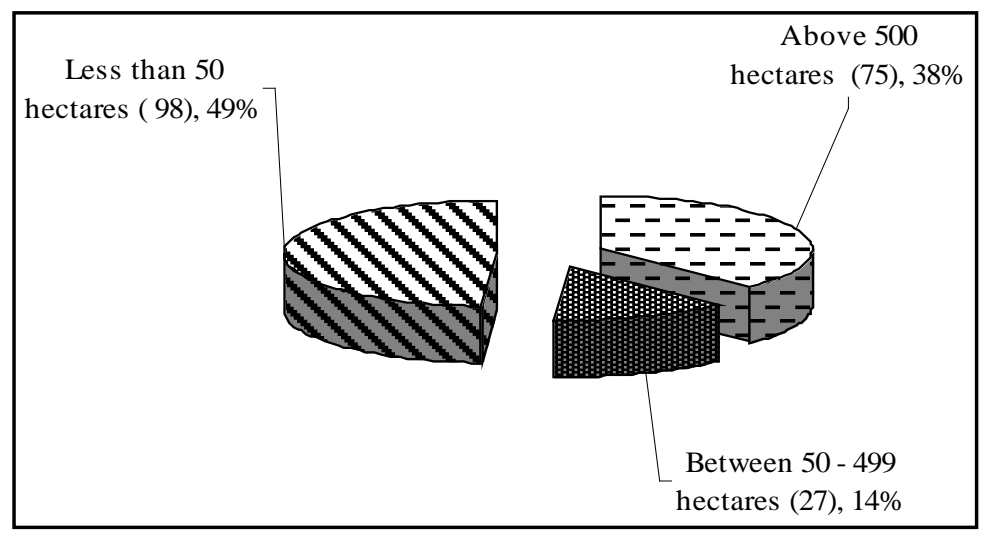

Figure 2. Total number of Game Ranches based on size by December 2012, Zambia.

Central Province ranked third with a total of 31 (16\% of national total). Of this total, 22 (71\%) were game ranch proper, ornamental 6 (19\%) and the least were game farms 3 (10\%). The province also had the largest number of Game ranch proper ( $\geq 500$ hectares) which were 22 (29\% of national total) (Figure 3(a), Figure 3(b)). Copper belt province had the fourth largest number of game ranches in the country 19 (10\% of national total). Of this total, 9 (47\%) were ornamental properties, while the other two categories had an equal number of 5 each (26.5\%).

Eastern and Northwestern provinces had the least 9 (4.5\% of national total each) and shared the same pattern of size where of the total 5 ( $55 \%$ each) were game ranches of the size equal to and larger than 500 hectares and 4 (45\% each) were ornamental. Muchinga Province had a total of 2 (1\% of national total) and both were of the size larger than 500 hectares.

Luapula, Western and Northern Provinces, despite being largely rural and not densely populated did not have any game ranch (Table 1, Figure 3(a), Figure 3(b)).

\subsubsection{Species of Large Mammals Popular on Game Ranching}

A total of 37 species of large mammals ( $\geq 5 \mathrm{~kg}$ ) were recorded with a total of 61,934 individuals. Of the 37 , two were exotic species, sported deer or Axis deer (Axis axis) donated by the Government of India to the Government of Zambia in the early 1980s and lowland nyala (Tragelaphus angasii) imported from the Republic of South Africa, the rest (35) were indigenous species.

Of these 37 species 15 were the most abundant with numbers exceeding 1000 individuals per species. These were in order of abundance as follows; impala (Aepyceros melampus), warthog (Phacochoerus africanus), bushbuck (Tragelaphus scriptus), common duiker (Sylvicapra grimmia), puku (Kobus vardoni), greater kudu (Tragelaphus strepsiceros), bush pig (Potamochoerus larvatus), sable antelope (Hippotragus niger), zebra (Equus quagga), reedbuck (Redunca arundinum), Kafue lechwe (Kobus leche kafuensis), eland (Taurotragus oryx), lichtensteini's hartebeest (Alcelaphus lichtensteini), defassa waterbuck (Kobus defassa), and common waterbuck (Kobus ellipsiprymnus) (Figure 4(a), Figure 4(b)).

\section{Discussion}

\subsection{Size of Game Ranches}

\subsubsection{Ornamental Properties}

Most ornamental properties were pre-existing fenced hotel and lodge premises as well as high cost residential properties. Therefore, no effort was required to secure land, fence and provide water; these requirements were already in place and since the properties were already on the title, all things that were required were to simply introduce game to add aesthetic value. In certain instances, only minor modifications were required such as improving the shape and configuration of drinking troughs and increasing the height of the enclosure in cases where animals such as impala or spotted deer which can jump over a 2.5 metre fence were concerned. Species diversity and animal numbers per property were also low and this lowered capital inputs and curtailed the lengthy and strenuous process required to establish a game ranch on virgin land. Since the properties were relatively 


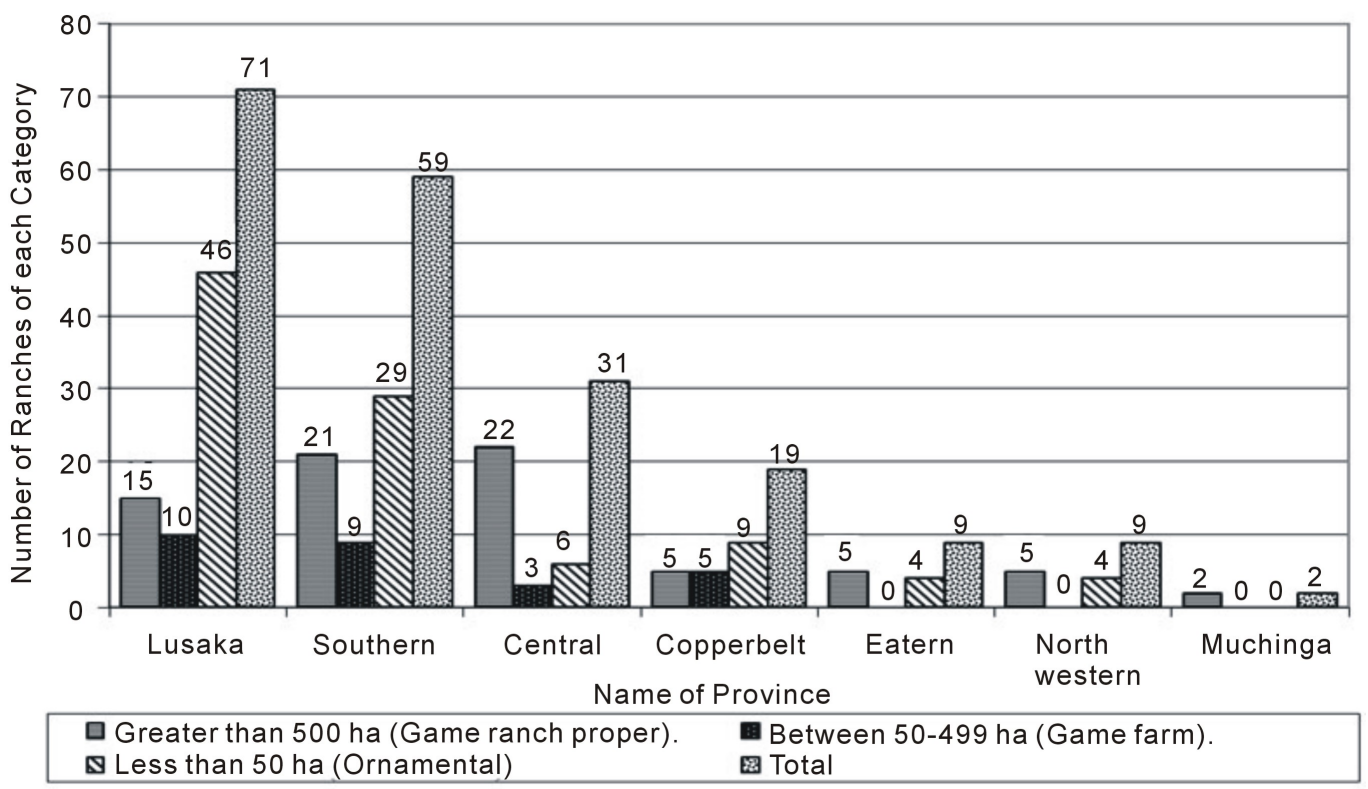

(a)

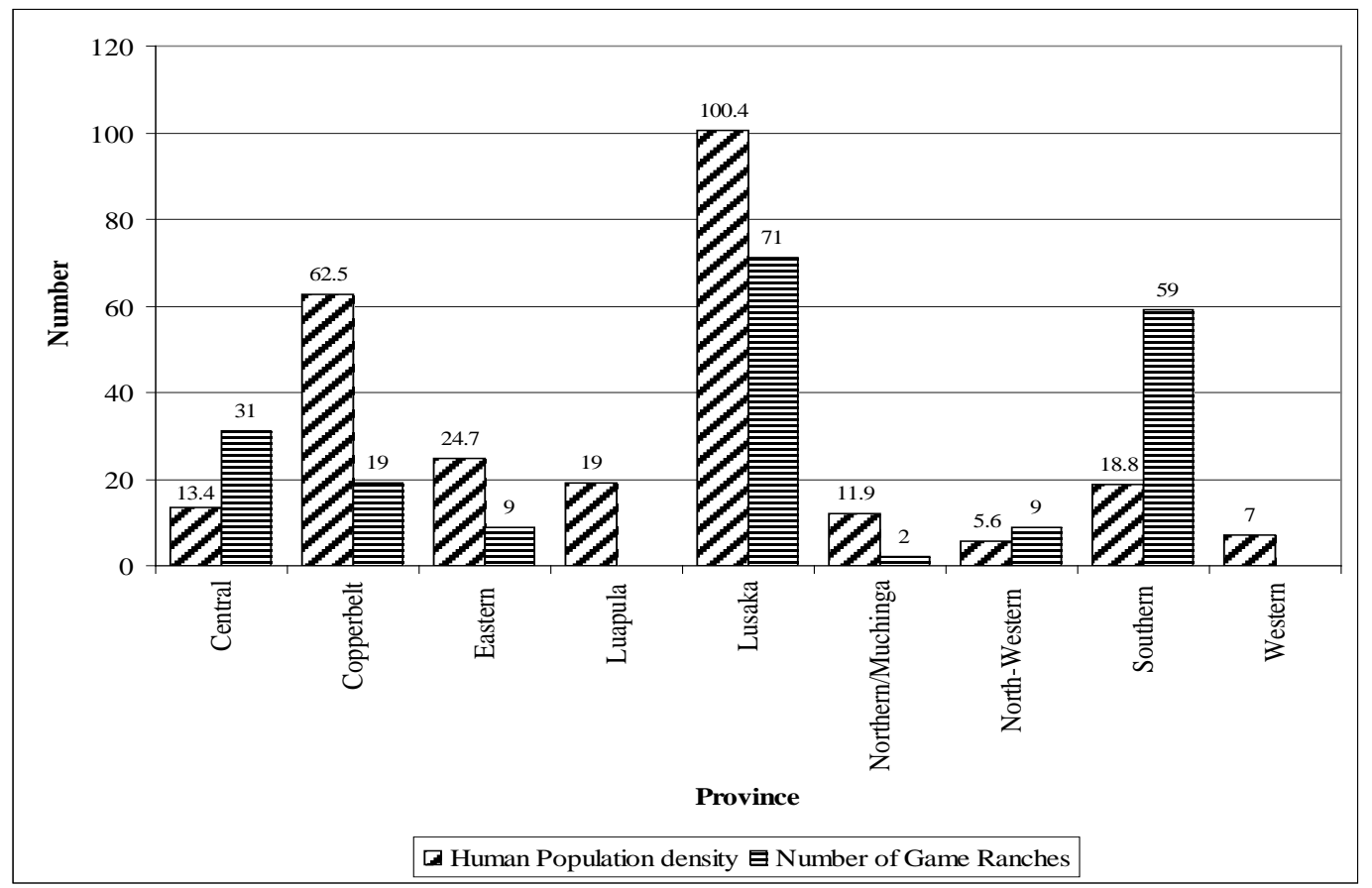

(b)

Figure 3. (a) Distribution of Game Ranches in each Province by end of year 2012; (b) Comparison of size of province, human population density and number of game ranches, Zambia.

small with respect to ranching, only few animals of mainly small to medium size which also cost less and transportation can be done in one truck load which is affordable made the process of establishment easier. The overall cost of commissioning the property was therefore generally low. Additionally, the increase in competition between tourist accommodation facilities mainly around Lusaka and Livingstone to elevate their aesthetic beauty in order to attract more visitors has also compelled many property owners to earn a competitive edge by introducing game around the property to enhance their attraction profile. The latter reason appears to have applied 
Table 1. Provinces, area in square kilometers, human population size and density compared with total number of established game ranches in each province, 2013, Zambia.

\begin{tabular}{ccccccc}
\hline Province & Provincial capital & Area $\mathrm{km}^{2}$ & Population size & $\begin{array}{c}\text { Population } \\
\text { density }\end{array}$ & $\begin{array}{c}\text { Number of } \\
\text { game ranches game ranch (ha.) }\end{array}$ \\
\hline Central & Kabwe & 94,394 & $1,267,803$ & 13.4 & 31 & 34,000 \\
Copperbelt & Ndola & 31,328 & $1,958,623$ & 62.5 & 19 & 3,600 \\
Eastern & Chipata & 69,106 & $1,707,731$ & 24.7 & 9 & 24,800 \\
Luapula & Mansa & 50,567 & 958,976 & 19.0 & - & - \\
Lusaka & Lusaka & 21,896 & $2,198,996$ & 100.4 & 71 & 36,189 \\
Northern/Muchinga & Kasama/Chinsali & 147,826 & $1,759,600$ & 11.9 & 2 & 11,600 \\
North-Western & Solwezi & 125,826 & 706,462 & 5.6 & 9 & 22,000 \\
Southern & Livingstone & 85,283 & $1,606,793$ & 18.8 & 59 & 45,000 \\
Western & Mongu & 126,386 & 881,524 & 7.0 & - & - \\
\hline
\end{tabular}

Notes: Data used in this table are for the period up to December 31, 2013; ${ }^{* *}$ Muchinga province was separated from Northern Province in 2011 and since then, there has been no census to determine its population size and in this report, it has been treated as part of Northern Province.

to high cost residential owners as well who would like to out compete their neighbours which eventually created a domino effect particularly in areas such as new Kasama high cost residential area of Lusaka. As neighbours learned from one another, it became relatively easy for the idea to spread quickly from one property owner to the other. This explains the almost exponential growth rates in ornamental category (see Figure 2) experienced in the last few years.

The reason for the relatively slow growth in the game farms cannot be readily explained. This is because the current Lands Act permits land acquisition not exceeding 250 hectares for agricultural purposes. Implying that it was easy to convert unproductive agricultural land to game farming but this was not the case. Perhaps the only explanation would be lack of knowledge in the majority of middle class Zambian citizens most of whom engage in maize production and other crops. Popular private enterprises for most Zambians in addition to farming seem to be those associated with law firms, construction, accommodation and transport.

\subsection{Distribution of Game Ranches in the Ten Provinces}

Lusaka, southern and central provinces were the leading provinces in the number and size of game ranching schemes, maintaining a skewed distribution across the ten provinces in the last 32 years. Most of the game ranches were still concentrated along the old line of rail. The skewed distribution of game ranches in favour of Lusaka and Southern provinces in particular, could be attributed to the increase in the number of hotels and lodges as well as residential properties where certain species of game are bred as a way of enhancing aesthetic beauty of their surroundings.

The rapid increase in the number of ornamental properties in the last few years was also attributed to the liberalization of the economy in 1991, after which the country experienced an increase in the establishment of tourist accommodation facilities and an emergence of the middle class. These tourist accommodation facilities as mentioned earlier usually keep game for ornamental purposes as one way of enhancing the attraction profile of their premises. Additionally, the increasing number of middle income groups and the rich increased the number of spacious high cost premises. In certain areas such as New Kasama in Lusaka, most property owners' stocked game around their premises, which were then classified as ornamental.

On private properties and tourist accommodation facilities, only game considered non dangerous to people were introduced and this explains why impala was the most abundant species. Large game is often considered dangerous and can only be found on medium to large size game ranches and not on residential properties or hotels. During the breeding season for instance, males of most species of wild animals in musth fight for females and some species also become aggressive towards both human and properties. For this reason, large game is not usually kept on residential properties. 


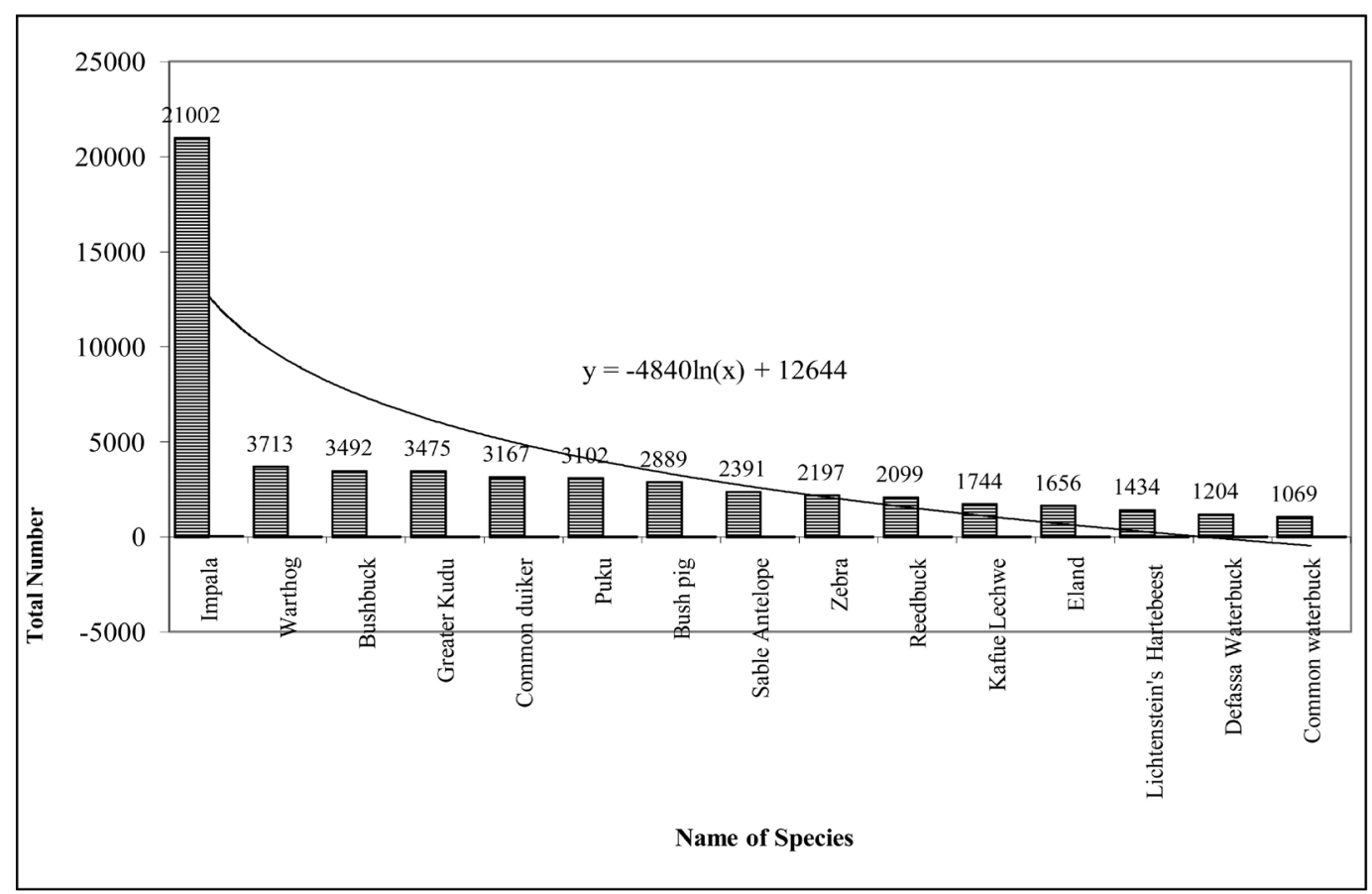

(a)

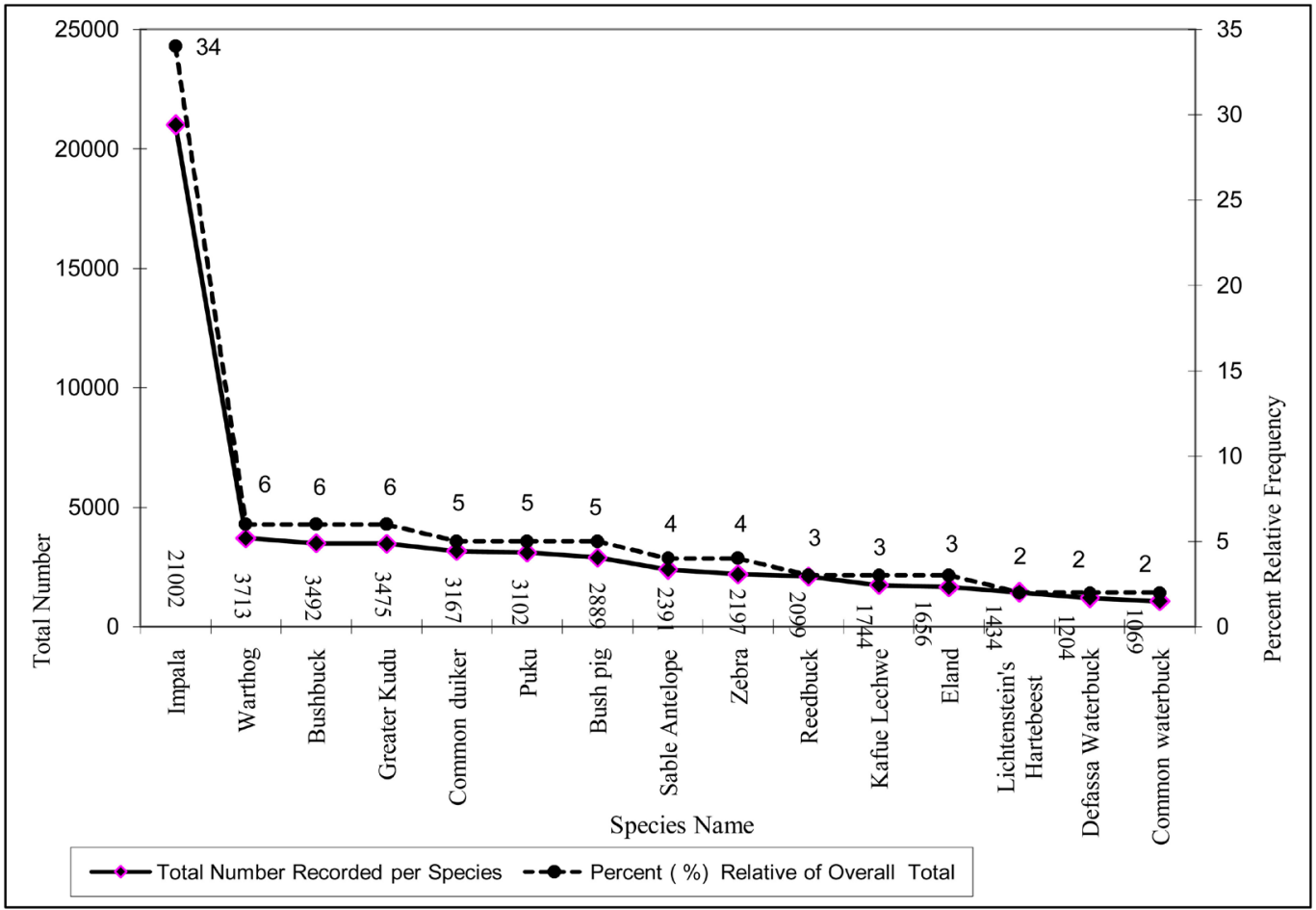

(b)

Figure 4. (a) Distribution of Game Ranches in each Province by end of year 2012, (b) Comparison of size of province, human population density and number of game ranches, Zambia.

\subsection{Game Ranching Schemes in Rural and High Rainfall Provinces}

The absence of game ranching schemes in Northwestern, Luapula and Northern Provinces and the small number 
of ranches in other rural provinces could be attributed to a number of factors including; long distance(s) from major cities and key tourist attractions such as the Mosi oa Tunya Falls, poor road net work and lack of air transport facilities. Lack of such facilities ultimately increase transportation costs and is a disincentive to the establishment of game ranching schemes. For example, it is difficult for foreign clients to reach these remote areas. Even if it were possible, the trip may not be rewarding as there are no other developed tourist attractions in the vicinity which would enrich the visitor's trip to justify the long and strenuous journey. In terms of trophy hunting, game ranches usually offer soft skin game hunting, implying that a client needs to go to another area for cats and big game, and as such, most clients would like to operate in an area where they can meet a full hunting package within a short distance, which saves time and money. It is hoped that through the current government programme "link Zambia 8000" many remote areas would be opened up to game ranching.

The other reason is that most provinces in agro ecological zones III and II have a common ecological limitation of dystrophic soils and hence poor pasture with coarse grasses such as Hyparrhenia spp dominating the range. Such grass species are of low nutritional value as they are dominated by sclerenchyma tissue with thick secondary walls containing lignin and hence unpalatable. In these areas which also have highly leached soils, stocking rates would not be high, except for bulky grazers. Eutrophic soils are normally found in drier ecological zones II and I and this may explain why most of the large game ranches are located in Southern Province. Similar observations were made in South Africa [10] [11] where the sweet veld carried a higher diversity and densities than sour velds.

\subsection{Popular Species for Game Ranching}

Impala was the most abundant species of the top 15 species on game ranches. It was also the most abundant even in the wild out numbering other bovines in Eastern and Southern Africa, gregarious and easy to capture, reproduces fairly quickly with gestation period of six months, has a smooth coat and good colour and hence attractive to look at, tames relatively easily save for the males who may be vociferous during rut when testosterone levels surge and they puff and grunt. At this time, they may cause some unintentional coalition with humans as was reported in Kafue National Park, Zambia, where they were responsible for most of the vehicle collisions [12]. Otherwise, impala is a successful species and this explains their abundance on ranches and in the wild. The absence of predators such as leopard (Panthera pardus) and wild dog (Lycaon pictus) on many game ranches implies that mortality is virtually absent and so the population may increase exponentially even with minimum management effort.

Buffalo (Syncerus caffer) was supposed to be one of the top 15 species as it is very popular in both hunting and photographic tourism. Every rancher saves for ornamental properties would like to have buffalo as a premium species on the property. The main challenges however, are the stringent veterinary legislative and policy frameworks which prohibit the capture and translocation of buffalo unless the specimens are Foot and Mouth Disease (FMD) free. FMD is a disease of concern because it is a highly contagious viral disease affecting practically all cloven-footed domesticated mammals, including cattle, sheep, goats, and pigs. It spreads rapidly and negatively impacts on animal productivity, and as such, it is considered to be the most economically devastating livestock disease in the world. To prevent the spread of FMD, the Department of Veterinary Services bans the movement or import of animals and animal products from known or suspected infected areas. Since buffalo is known to be a carrier of the virus, its movement is prohibited unless tests are carried out to prove that the specimen is FMD free. It is the huge costs involved in raising FMD free calves that makes it prohibitive and prevents most farmers from purchasing buffalo. This could be the reason why buffalo was not one of the top 15 species.

Roan antelope numbers were low, perhaps because it is not easy to obtain breeding stock. The numbers are low everywhere including in National Parks and Game Management Areas. Getting a large founder may not have been practicable. Breeding of this species also appears to be slower than its relative the sable antelope for reasons that are not very clear at the moment, though others associate this to habitat quality. For a few years to come, roan antelope numbers at each property may continue to be low. Warthog and other members of the family suidae have large litters and populations increase quickly and in many ranches, the species is said to be stable to increasing. This species is expected to increase on every property where they exist.

Cats are virtually absent on all properties, due to legislative restrictions and because many farmers feel that their presence on the ranch increases calf mortality of antelope species. On the few properties on which they ex- 
ist, they are confined to enclosures and are fed artificially which increases costs. Captive breeding and cat hunting are not allowed in Zambia, so the incentive to encourage ranchers to breed them is logically curtailed.

The absence of rhino can be explained by the current legislative and policy restrictions and high security costs. Under the current policy, rhino can only be kept on a private property under custodianship arrangements. Many property owners also feel that it would be risky to keep rhinos on private property, particularly beginning 2008 when poaching started to increase to unprecedented levels to the extent that even in South Africa which has the highest investment in security on the African continent, started to lose more than 600 animals each year (2008-2013). The poaching scourge for rhino increased due to a sudden upsurge of rhino horn price on the black market particularly in Vietnam where it was estimated to cost no less than US\$ 65,000 per kg (March 2014) or in extreme circumstances up to USD 1400 as was once recorded in Vietnam in 2013. This had made rhino security a risk and probably discouraged new property owners in Zambia from keeping rhino even under custodianship arrangements, as the cost of doing so may far exceed benefits.

\section{Recommendations}

The game ranching sector in Zambia has the potential to increase as human population density is still low $\left(17 / \mathrm{km}^{2}\right)$. To achieve good growth rates in each province there should be provision of technical information and services. This would to enable new entrants to manage the range in a professional manner as to increase stocking rates. The following suggestions are made to support growth of the sector:

1) Growing of Lurcene/Alfalfa (Medicago sativa) which is a nutritious fodder crop rich in proteins, minerals and vitamins should be encouraged. Lurcene can with stand extremes of drought and this makes it remarkably adaptable to various climatic conditions and its wide spread use in Zambia can revolutionarize game ranching as well as live stock raising and should be considered as a priority programme to be implemented side by side with game ranching. To speed up this process, the local academic institutions such the University of Zambia, Copperbelt University and Mulungushi University should be willing and ready to offer technical training and outreach programmes to communities.

2) In areas along the Tanzania-Zambia Railways (TAZARA) corridor, it would be advisable to encourage ranching as the area is already accessible by train. Additionally, ranching schemes in the high rainfall ecological zones, should consider managing such properties as integrated production systems, which would also include bee keeping, and in some instances aquaculture on the same property to increase profit margins and leverage lower stocking rates.

3) In Western Province where the land tenure systems highly engrained in traditional systems, it would be advisable for government to engage traditional authorities there to release land for ranching. In Luapula and Northern Provinces, the major factor could be inadequate air and road support infrastructure coupled with the absence of cattle keeping tradition. In Luapula Province for instance, fishing in natural water bodies which are in fact in abundance, is a major occupation and ranching would be considered alien. In these areas establishment of game ranching schemes should be preceded by massive awareness campaigns.

\section{Acknowledgements}

We wish to thank staffs of licensing and research departments of Zambia Wildlife Authority in particular Mr. Daniel Mwizabi a research assistant at ZAWA for collecting data from the field, Mr. Ngubu a student on attachment from the University of Zambia for entering data on excel spread sheets, Mr. Ignatius Mulembi of the Licensing Office for providing documents which contain duplicate copies of the Certificates of Ownership, Mr. Musonda for his skillful and careful driving during routine visits to Game Ranches. Many anonymous readers that made contributions and critique of the initial draft summarizing it from several pages to the present succinct account. We thank them all for the effort.

\section{References}

[1] Chansa, W., Kampamba, G., Siamudaala, V. and Changwe, K. (2005) Management Guidelines for Private Wildlife Estates in Zambia. Zambia Wildlife Authority, Chilanga, 1-9.

[2] Chansa, W., Kampamba, G. and Changwe, K. (2005) General Guidelines for Conducting Ecological Assessments for the Establishment and Management of Game Ranching Operations in Zambia. Zambia Wildlife Authority, Chilanga, $1-51$. 
[3] Anon (2012) Game Time, the Changing Face of South African Farming. Financial Mail, 27-54.

[4] Absa Group of Economic Research (2003) Game ranch Profitability in Southern Africa. Monty Print cc. Rivonia, 1-83.

[5] Mwenya, A.N. (2009) Game Ranching. Zambian Economist, 49-50.

[6] Chansa, W. and Wagner, P. (2006) On the Status of Malachochersus tornieri (Siebenrock, 1903) in Zambia. Salamandra (Journal of Herpetology), 42, 187-190.

[7] Kingdon, J. (2008) The Kingdon Field Guide to African Mammals. A\& C Black, London.

[8] Anon (2002) Game Ranching Policy for Botswana. Ministry of Trade, Industry and Tourism, Botswana Government Printer, Gaborone.

[9] Chansa, W., Siamudaala, V., Kampamba, G. and Changwe, K. (2005) The National Crocodile Conservation Plan. Zambia Wildlife Authority, Chilanga, 1-37.

[10] Siamudaala, V. (2000) Draft Policy on Private Wildlife Estates-Game Ranching and Other Novel Uses. Zambia Wildlife Authority, Chilanga, 1-27.

[11] Smit, N. (2005) Calculating Your Land’s Game Carrying Capacity. Farmers Weekly, 44-46.

[12] Mkanda, F.X. and Chansa, W. (2011) Changes in the Temporal and Spatial Pattern of Road Kills along the Lusaka-Mongu (M9) Highway, Kafue National Park, Zambia. South African Journal of Wildlife Research, 41, 68-78. http://dx.doi.org/10.3957/056.041.0114 